\title{
PENGARUH PENDEKATAN PENDIDIKAN MATEMATIKA REALISTIK TERHADAP KEMAMPUAN PENALARAN MATEMATIS SISWA KELAS V PADA MATERI BANGUN RUANG
}

\author{
Abdiani Luthfiana Ulya \\ Institut Pesantren KH. Abdul Chalim, Mojokerto, Indonesia \\ E-mail: alulya03@gmail.com \\ Yhasinta Agustyarini \\ Institut Pesantren KH. Abdul Chalim, Mojokerto, Indonesia \\ E-mail: yhasintaagustyarini@yahoo.com
}

\begin{abstract}
The results of the PISA in 2018 where Indonesia take place 72th of 79th country. One of the factors is the learning that has not pay attention to aspects of students' mathematical reasoning abilities. RME approach is emphasize on creative thought process and involves student's reasoning abilities. This research aims to determine the influence of the Indonesia's Realistic Mathematics Education approach on mathematical reasoning abilities students grade $\mathrm{V}$ on geometry lesson. The type of this research is one group pretest posttest design. The population consisted of 86 student who sat in class IV, V and VI then selected 12 children from class $\mathrm{V}$ as a sample that was given treatment with the RME approach. Technique to collect data using tests, interview, and questionnaires. The results of data analysis showed that students' mathematical reasoning increased from a pretest score 64 increased at posttest to 80 . Then using analyze of paired sample t-test with $\alpha=0.05$ obtained tcount $=7.881>$ ttable $=2.201$ so that $\mathrm{H} 0$ is rejected and $\mathrm{Ha}$ is accepted. Then it can be concluded that the Indonesia's Realistic Mathematics Education approach is influence to the mathematical reasoning abilities of students grade $\mathrm{V}$ on geometry lesson.
\end{abstract}

Keywords: RME Approach, Reasoning Abilities, Geometrty

\begin{abstract}
Abstrak: Hasil skor PISA pada 2018, Indonesia menempati tempat 72 dari 79 negara. Salah satu penyebabnya yaitu aspek penalaran kurang diperhatikan dalam pembelajaran. PMRI merupakan pendekatan yang menitikberatkan pada proses berpikir aktif dan melibatkan penalaran siswa. Penelitian ini untuk mengetahui pengaruh pendekatan PMRI terhadap kemampuan penalaran matematis siswa kelas $\mathrm{V}$ pada materi bangun ruang. Jenis penelitian menggunakan one group pretest posttest design. Populasi penelitian adalah 86 siswa kelas tinggi dan dipilih 12 anak dari kelas $\mathrm{V}$ sebagai sampel yang diberikan perlakuan dengan pendekatan PMRI. Hasil analisis data menunjukkan bahwa kemampuan penalaran matematis siswa meningkat dari skor pretest sebesar 64 meningkat pada posttest menjadi 80 . Hasil analisis data uji paired sample t-test dengan $\alpha=0,05$ diperoleh thitung $=7,881>$ ttabel $=$ 2,201 sehingga H0 ditolak dan Ha diterima. Maka dapat disimpulkan bahwa pendekatan Pendidikan Matematika Realistik Indonesia (PMRI) berpengaruh terhadap kemampuan penalaran matematis siswa kelas $\mathrm{V}$ pada materi bangun ruang.
\end{abstract}

Kata Kunci: Pendekatan PMRI, Kemampuan Penalaran Matematis, Bangun Ruang 


\section{Pendahuluan}

Menurut PP Nomor 22 Tahun 2016, standar proses pembelajaran pada satuan pendidikan adalah pembelajaran diselenggarakan dengan interaktif, menyenangkan, penuh inspirasi, menantang dan dapat mendorong siswa agar lebih aktif partisipatif, serta pembelajaran yang menyediakan cukup ruang bagi kreativitas, prakarsa, dan kemandirian sesuai minat dan bakat, dan perkembangan jasmani maupun rohani yang didapatkan dari teladan pendidik. ${ }^{1}$ Dengan berpedoman pada standar tersebut, beberapa upaya pemerintah dalam peningkatan kualitas Pendidikan di Indonesia dilakukan, salah satunya yaitu melalui mata pelajaran wajib yang disampaikan kepada siswa di sekolah.

Matematika merupakan salah satu pelajaran wajib yang disampaikan di sekolah tingkat dasar hingga tingkat menengah. Karakteristik matematika sekolah antara lain memiliki objek kajian konkret dan abstrak; menggunakan pola pikir induktif dan deduktif. Karakteristik matematika yang abstrak itulah yang menjadikan anak sulit untuk mempelajari matematika. ${ }^{2}$ Mata pelajaran matematika sangat perlu diberikan kepada siswa dalam rangka membekali siswa dengan kemampuan berpikir sistematis, logis, analitis dan kritis serta berpikir kreatif berikut keterampilan kerjasama. Karena itu, mata pelajaran matematika sebaiknya disampaikan bukan hanya dengan metode pembelajaran ceramah yang menjadikan anak pasif.

Pentingnya matematika dijelaskan dalam Al-Quran, seperti tercantum dalam ayat berikut:

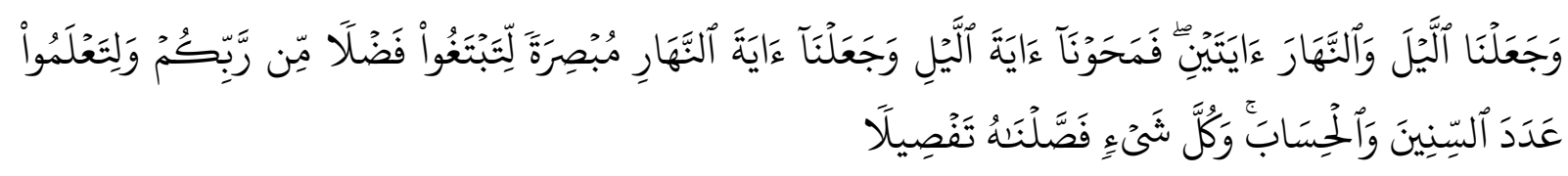

Artinya: 'Dan Kami jadikan malam dan siang sebagai dua tanda, lalu Kami hapuskan tanda malam dan Kami jadikan tanda siang itu terang, agar kamu mencari kurnia dari Tubanmu, dan supaya kamu mengetahui bilangan tabun-tahun dan perbitungan. Dan segala sesuatu telah kami terangkan dengan jelas. (QS. Al-Israa:12). ${ }^{3}$

Sampai saat ini, matematika masih menjadi momok bagi sebagian peserta didik di Indonesia. $\mathrm{Hal}$ ini dapat dilihat dari penelitian pendahuluan yang dilakukan pada siswa kelas V SDN Trucuk II Bojonegoro diperoleh hasil sebagian besar siswa menganggap matematika merupakan pelajaran yang paling sulit di sekolah.

Menurut NCTM (National Council of Teacher Mathematics) salah satu kemampuan yang seharusnya dimiliki siswa ialah kemampuan penalaran (reasoning and proof). Penalaran merupakan suatu proses berpikir pada penarikan kesimpulan yang berbentuk pengetahuan dan memiliki suatu karakteristik agar kebenaran dapat ditemukan. Kemampuan bernalar merupakan kemampuan siswa dalam berpikir secara logis atau masuk akal dan menurut rangkaian alur berpikir tertentu. ${ }^{4}$ Menurut NCTM (The National Council of Teachers of Mathematics) penalaran menjadi bagian yang tidak dapat dipisahkan dari matematika. Siswa sebaiknya memiliki pandangan bahwa dalam matematika turut terdapat kegiatan pemeriksaan pola dari konsep, pencatatan keteraturan, menghasilkan dugaan dan mengevaluasinya. ${ }^{5}$

(Sumarmo, 2005) menyebutkan dalam matematika terdapat 9 indikator kemampuan penalaran matematis, yaitu siswa dapat: Menarik kesimpulan yang logis; Menjelaskan dengan model, fakta,

\footnotetext{
1 Badan Standar Nasional Pendidikan, Salinan PP Nomor 22 Tahun 2016, (Online), http://bsnp-indonesia.org , diakses pada 10 Februari 2020

2 Susanah, Matematika dan Pendidikan Matematika, Modul, (Jakarta: Universitas Terbuka), hlm. 1.23-1.24.

${ }^{3}$ Departemen Agama RI, Al- Qur'an dan Terjemahannya, (Jakarta: CV. Pustaka Agung Harapan: 2006), (17: 12).

4 Widayanti Nurma Sa'adah, Peningkatan Kemampuan Penalaran Matematis Siswa Kelas VIII SMP Negeri 3 Banguntapan dalam Pembelajaran Matematika melalui PMRI, (Yogyakarta: UNY, 2010)

5 Aji Wibowo, Pengarub Pendekatan PMRI, (2017).
} 
sifat dan hubungan; Memberi dugaan solusi; Penggunaan pola dalam analisis situasi; dan Menyusun dan pengujian dugaan. ${ }^{6}$ Pada penelitian ini, kemampuan penalaran matematis yang dimaksud meliputi penyelesaian masalah dan penemuan pola, pembuatan generalisasi dan mengevaluasi argumen matematika.

Terdapat dua jenis penalaran, yaitu penalaran deduktif dan penalaran induktif. Penalaran induktif berangkat dari suatu pernyataan yang akan dibuktikan kebenarannya dengan dugaan yang berasal dari intuisi maupun dari suatu data. Penalaran induktif dilakukan dengan mengorganisasikan data sampai dapat diambil kesimpulan umum. Kesimpulan yang didapat itu disebut dengan teorema dugaan. Dimana dugaan sementara tersebut masih butuh pembuktian kebenarannya dengan penalaran deduktif. Sedangkan penalaran deduktif yaitu penalaran yang berfungsi sebagai pembuktian teorema atau dugaan. Hal ini dilakukan dengan penurunan teorema yang berasal dari definisi, aksioma ataupun teorema yang dibuktikan berdasarkan pemikiran logis. ${ }^{7}$

Dalam matematika, penalaran induktif digunakan agar mendapatkan dugaan mengenai teorema atau rumus yang digunakan. Selain itu penalaran induktif urgent pada proses pembelajaran di sekolah, khususnya di SD dan SMP karena pembelajaran ini mudah diikuti oleh para siswa. Penalaran induktif dilakukan dengan merangkai kesimpulan yang bersifat umum. Dimana kesimpulan itu didapatkan dari proses percobaan ataupun contoh-contoh. ${ }^{8}$

Dimana penalaran merupakan kemampuan mengemukakan alasan dalam mengonstruksi suatu pernyatan matematika serta mengembangkan pembuktian matematika. Sehingga kemampuan penalaran ialah kemampuan ketika membuat suatu dugaan dan kesimpulan, serta membuat argumen dari dugaan tersebut berdasarkan fakta-fakta yang dimilikinya. Oleh karena itu, teori dalam matematika dapat dipahami dengan baik jika siswa juga memiliki penalaran yang baik.

Realitasnya, sebagian besar dari jumlah siswa masih mengalami kesulitan untuk menggunakan kemampuan bernalarnya dalam penyelesaian soal matematika. Hal ini dapat dilihat dari rendahnya skor matematika Indonesia yang menempati 10 terbawah pada PISA (Programme for International Student Assessment) dan TIMSS (Trends in International Mathematics and Science Study).

Kondisi yang terjadi di lapangan ini dapat terjadi karena beberapa faktor, misalnya penggunaan metode dan media yang belum efektif dalam proses pembelajaran. Berdasarkan pra penelitian yang dilakukan di SD Negeri Trucuk II, guru kelas V belum menggunakan metode pembelajaran yang mendorong siswa lebih aktif berpikir menggunakan penalaran. Guru lebih sering menggunakan metode ceramah saat menyampaikan materi di kelas. ${ }^{9}$

Pembelajaran Matematika dianjurkan menggunakan metode yang mengacu pada teori belajar konstruktivisme dimana teori ini membuat siswa menjadi berpikir aktif dan melibatkan penalaran siswa secara langsung. Pendekatan sains, teknologi dan masyarakat yang digunakan pada proses belajar mengajar membuat siswa lebih mudah dalam memahami dan mengingat saat menggunakan masalah dalam kehidupan sehari-hari. ${ }^{10}$ Berdasarkan analisis kebutuhan siswa tersebut maka salah satu alternatif solusinya adalah dengan menggunakan pendekatan realistik.

Di Indonesia, konsep pendekatan RME dikenali juga sebagai PMRI (Pendekatan Matematika Realistik Indonesia). Dimana PMRI mengkombinasikan beberapa pandangan tentang hakikat matematika, bagaimana siswa seharusnya belajar matematika, serta bagaimana mengajarkan

\footnotetext{
${ }^{6}$ Niluh \& Endang, Instrumen Penelitian "Kemampuan Matematika”, makalah, (Yogyakarta: Universitas Negeri Yogyakarta, 2012), 8

${ }^{7}$ Sukirman dkk, Matematika, Modul , (Jakarta: Penerbit Universitas Terbuka), 2-2.3

8 Sukirman dkk, Matematika, 2.23

${ }^{9}$ Berdasarkan survey dan wawancara pra observasi, (Bojonegoro: 9 Juni 2020) (terlampir)

10 Dwi Sulistya Kusumaningrum, Peningkatan Kemampuan dan Kemandirian Belajar Matematika Melalui Pendidikan Matematika Realistik Indonesia (PMRI) untuk Siswa SMP,2016, jurnal, vol.1, no. 1
} 
matematika yang seharusnya. ${ }^{11}$ Pendidikan Matematika Realistik Indonesia (PMRI) merupakan bentuk adaptasi RME di Indonesia yang selaras dengan kondisi budaya, geografi, dan kebiasaan masyarakat Indonesia. ${ }^{12}$ Implementasi PMRI digagas pertama kali di Indonesia oleh Sembiring. Menurutnya, pembelajaran yang menggunakan pendekatan PMR mampu merubah matematika yang sifatnya abstrak (sulit dibayangkan) menjadi lebih nyata dan kontekstual bagi siswa. Hal ini dapat melatih siswa untuk lebih percaya diri dalam penyampaian suatu gagasan dengan logis. ${ }^{13}$

Berdasarkan pendapat beberapa ahli pada uraian tersebut, dapat diambil kesimpulan bahwa Pendidikan Matematika Realistik Indonesia (PMRI) adalah pendekatan yang digunakan dalam proses pembelajaran matematika. Dimana dalam pendekatan ini berorientasi pada penggunaan masalah real dimana siswa bisa membayangkan masalah tersebut yang kontennya selaras dengan budaya masyarakat Indonesia dengan tujuan untuk melatih kepercayaan diri dan menyampaikan gagasan dengan masuk akal.

Suatu proses pembelajaran disebut menerapkan pendekatan PMRI ketika dalam pembelajaran matematika tersebut mengandung 5 karakteristik dari PMRI (Treffers, 1987), yaitu sebagai berikut: Penggunaan Konteks, Penggunaan Model, Pemanfaatan hasil kerja dan konstruksi siswa, Interaktivitas, dan Keterkaitan (intertwining). ${ }^{14}$ PMRI merupakan inovasi dalam pendekatan pembelajaran matematika dan sesuai dengan kondisi budaya yang jika menggunakan prinsipprinsip dalam PMRI di Indonesia akan berpotensi untuk meningkatkan hubungan interaksi dan koneksi siswa.

Dari hasil penelitian Adzni (2019) menunjukkan bahwa PMRI menjadi salah satu alternatif dalam pencapaian penalaran induktif siswa. Selain itu, Febriani (2017) juga mengatakan dari hasil penelitiannya bahwa Pembelajaran RME dan Pembelajaran Langsung dapat meningkatkan berpikir kreatif dan kemampuan penalaran matematis peserta didik. Menurut hasil penelitian Iga Octriana (2018) menunjukkan bahwa penalaran matematis siswa dapat ditingkatkan melalui penggunaan pendekatan PMRI dan LSLC.

Dari latar belakang yang telah dipaparkan di atas, menjadi penting untuk dibahas. Adapun rumusan masalah dalam penelitian ini yaitu apakah penggunaan PMRI berpengaruh dalam peningkatan penalaran matematis siswa pada materi bangun ruang di kelas V SD Negeri Trucuk II melalui penelitian dengan judul "Pengaruh Pendekatan Pendidikan Matematika Realistik Indonesia (PMRI) terhadap kemampuan penalaran matematis siswa kelas $\mathrm{V}$ materi bangun ruang".

\section{Metode Penelitian}

Penelitian ini merupakan penelitian kuantitatif dengan menggunakan metode eksperimen tipe one group pretest posttest design. Pendekatan yang dipakai dalam penelitian in adalah pendekatan kuantitatif dengan menggunakan metode eksperimen tipe One Group Pretest Posttest Design. Yaitu dimana diberikan pretest sebelum treatment (perlakuan) dan setelah perlakuan diberikan posttest. Hal ini bertujuan untuk megetahui keakuratan karena dapat membandingkan sebelum dan sesudah perlakuan.

Populasi penelitian yaitu siswa kelas tinggi di SDN Trucuk II yang berjumlah 86 siswa. Dari populasi tersebut diambil sampel dengan teknik purposive sampling atau memilih sampel dengan tujuan tertentu. Dalam hal ini, pengambilan sampel bertujuan untuk memperoleh siswa yang

\footnotetext{
11 Sutarto Hadi, Pendidikan Matematika Realistik: Teori, Pengembangan dan Implementasinya. (Jakarta: RajaGrafindo Persada, 2017) hlm. 8

12 Sutarto Hadi, Pendidikan Matematika Realistik, (1 ed: Jakarta: Rajawali Pers, 2017)

13 Sutarto Hadi, Pendidikan Matematika Realistik.

${ }^{14}$ Susilahudin Putrawangsa, Desain Pembelajaran Matematika Realistik, (Mataram: CV. Reka Karya Amerta, 2017),17-18.
} 
mempunyai kemampuan penalaran matematis cukup dan domisilinya tidak jauh dari tempat pembelajaran. Berdasarkan pertimbangan tersebut, maka peneliti mengambil sampel dengan pertimbangan dari seorang guru yang mengajar Matematika kelas V. Berdasarkan hasil wawancara tersebut, kemudian ditentukan sampelnya ialah beberapa siswa kelas V di SDN Trucuk II Tahun Pelajaran 2019/2020 yang berdomisili tidak jauh dari penelitian, yaitu sebanyak 12 anak.

Lokasi penelitian terdiri dari tiga tempat, yaitu Sekolah Dasar Negeri II; rumah peneliti; dan rumah salah satu siswa. Teknik pengumpulan data yang digunakan yaitu wawancara, test, kuesioner dan dokumentasi. . wawancara digunakan dalam rangka menggali informasi tentang proses pembelajaran di kelas, dan penalaran matematis siswa maka dilakukan wawancara semi terstruktur dengan guru matematika kelas V SDN Trucuk II. Dalam rangka mendapatkan data pendukung terkait bagaimana pelaksanaan pembelajaran, digunakan dokumentasi untuk mengumpulkan data. Selain itu juga data-data lain dari sekolah yang diperlukan dan yang mendukung proses maupun pelaporan penelitian dikumpulkan dari dokumetasi. Untuk mengukur kemampuan penalaran matematis siswa digunakan instrumen berupa soal uraian yang terdiri dari 8 soal essay yang diterapkan pada pretest dan posttest. Instrumen soal disusun berdasarkan KI dan $\mathrm{KD}$ mata pelajaran matematika kelas 5 materi bangun ruang dan berdasarkan indikator kemampuan penalaran matematis yang telah ditentukan sebelumya. Paparan indikator tersebut dapat dilihat pada tabel 2.2 berikut.

\section{Tabel 1. Indikator dan Deskriptor Kemampuan Penalaran Matematis}

\begin{tabular}{llll}
\hline No & \multicolumn{1}{c}{ Indikator } & \multicolumn{3}{c}{ Deskriptor } \\
\hline 1 & $\begin{array}{l}\text { Pernyataan matematika } \\
\text { disajikan tertulis }\end{array}$ & $\begin{array}{l}\text { Siswa dapat menemukan informasi dari suatu kasus } \\
\text { dengan baik }\end{array}$ \\
\hline 2 & Mengajukan dugaan & $\begin{array}{l}\text { Siswa dapat memberikan jawaban atau dugaan } \\
\text { sementara. }\end{array}$ \\
\hline 3 & $\begin{array}{l}\text { Menarik kesimpulan dan } \\
\text { penyusunan bukti }\end{array}$ & $\begin{array}{l}\text { Siswa dapat memberi alasan dari suatu pernyataan dan } \\
\text { dapat menyimpulkan jawaban yang diperoleh }\end{array}$ \\
\hline 4 & $\begin{array}{l}\text { Melakukan } \\
\text { matematika }\end{array}$ & manipulasi & $\begin{array}{l}\text { Dalam menyelesaikan soal., siswa menggunakan } \\
\text { caranya sendiri berdasarkan pengalaman yang dimiliki. }\end{array}$ \\
\hline 5 & $\begin{array}{l}\text { Memberikan kesahihan suatu } \\
\text { argumen. }\end{array}$ & Siswa memeriksa kembali atas jawabannya. & \\
\hline
\end{tabular}

Sebelum diterapkan, dilakukan pengujian instrumen dengan analisis validitas, reliabilitas dan analisis butir soal. Validitas instrumen dilakukan dengan expert judgement untuk menilai validitas isi, dan digunakan rumus product moment correlations untuk mengukur validitas tiap butir soal. Untuk mengukur reliabilitas soal digunakan rumus Alpha Cronbach. Analisis data yang digunakan untuk menguji hipotesis yaitu analisis statistik parametrik, sehingga data diperiksa normalitasnya terlebih dahulu. Untuk menguji normalitas data dalam penelitian ini digunakan rumus Liliefors. Kemudian dilakukan analisis data dengan uji pair sample t-test untuk mencari pengaruh PMRI terhadap kemampuan penalaran siswa dan untuk membandingkan sebelum dan sesudah perlakuan PMRI pada siswa kelas V SDN Trucuk II.

\section{Hasil Uji Instrumen}

Pada penelitian ini, digunakan instrumen berupa soal berbentuk esai yang terdiri dari 8 soal untuk mengukur kemampuan penalaran matematis siswa. Pengujian instrumen dilaksanakan untuk memperoleh data mengenai proses dan hasil belajar siswa yang lebih akurat.Sebelum digunakan, dilakukan pengujian instrument dengan analisis validitas, reliabilitas, daya beda dan 
tingkat kesukaran dari soal yang digunakan. Berikut ini akan diuraikan hasil analisis dari soal penalaran matematis.

\section{Validitas isi}

Validitas isi digunakan untuk menilai instrumen dipandang dari segi isi (content) yang dapat berupa materi pembelajaran yang tercakup dalam instrumen tersebut. ${ }^{15}$ Penilaian instrumen dari segi isi atau kontennya dilakukan dengan experts judgement oleh Dosen, yaitu ibu Yhasinta Agustyarini, M.Pd dan Guru SD, ibu Nurul Budiyanti, S.Pd dengan mengisi lembar validitas berupa daftar checklist yang telah di sediakan. Instrumen dinilai berdasarkan dari segi materi, bahasa, dan kurikulum yang harus disesuaikan dengan siswa. Hasil penilaian oleh ahli didapatkan hasil "valid" sehingga instrumen soal tes dapat digunakan.

\section{Validitas Hubungan Kriteria}

Setelah validitas isi dilakukan, kemudian dilakukan uji validitas konstruk dari instrumen penalaran matematis. Sebuah tes disebut mempunyai validitas konstruk jika skor pada butir item memipunyai kesesuaian dengan skor totalnya. ${ }^{16}$ Validitas ini dihitung dengan korelasi product moment dengan aplikasi Microsoft excel. Pada tabel 4.2 berikut ditunjukkan hasil $\mathrm{r}_{\mathrm{xy}}$ dari setiap soal.

Tabel 2. Hasil Hitung Validitas Setiap Butir Soal

\begin{tabular}{cccc}
\hline No. Butir Soal & $\mathbf{r}_{\text {hitung }}$ & $\mathbf{r}_{\text {tabel }} \mathbf{5 \%}(\mathbf{1 0 )}$ & Kriteria \\
\hline 1 & 2,459 & & Valid \\
\hline 2 & 1,921 & & Valid \\
\hline 3 & 2,347 & & Valid \\
\hline 4 & 3,121 & \multirow{2}{*}{1,782} & Valid \\
\hline 5 & 3,483 & & Valid \\
\hline 6 & 4,033 & & Valid \\
\hline 7 & 1,735 & & Valid \\
\hline 8 & 3,408 & & valid \\
\hline
\end{tabular}

Dari hasil hitung $r_{x y}$ dari setiap butir soal di atas dapat dianalisis bahwa nilai $r_{x y}>r_{\text {tabel }}$. Sehingga dapat disimpulkan setiap butir soal penalaran matematis tersebut adalah valid.

\section{Analisis Reliabilitas}

Uji reliabilitas diterapkan dalam menentukan tingkat kekonsistenan hasil dari pengukuran, jika dilakukan pengukuran berkali-kali terhadap kondisi tertentu dengan alat pengukur yang sama. ${ }^{17}$ Analisis reliabilitas diuji dengan menggunakan rumus Alfa Cronbach. Dimana hasil perhitungan dari setiap butir soal ditunjukkan pada tabel 3.

Tabel 3. Analisis Reliabilitas Soal

\begin{tabular}{ccc}
\hline Analisis & Hasil & Kategori \\
\hline $\mathrm{N}$ & 8 & Tinggi \\
\hline $\mathrm{r}_{11}$ & 0,7982 & T
\end{tabular}

Dari tabel 3. didapatkan bahwa nilai dari $r_{11}$ yaitu sebesar 0,836, lebih besar dari 0,60. Maka dapat disimpulkan soal reliabel. Selanjutnya nilai 0,836 dimasukkan ke dalam kriteria, sehingga

${ }^{15}$ Ida Farida, Evaluasi Pembelajaran Berdasarkan Kurikulum Nasional, (Bandung: PT Remaja Rosdakarya, 2017), hlm. 159.

${ }^{16}$ Anas Sudijono, pengantar Evaluasi Pendidikan, (Jakarta: PT Raja Grafindo, 2013)

${ }^{17}$ Syofian, Metode Penelitian Kuantitatif, 57 
dapat diambil kesimpulan bahwa soal yang dianalisis mempunyai reliabilitas dengan kategorinya sangat tinggi.

\section{Analisis Butir Soal}

\section{Tingkat Kesukaran}

Analisis Indeks kesukaran (difficulty index) diperlukan untuk mengetahui sulit atau tidak dari suatu instrumen soal. ${ }^{18}$ Analisis indeks kesukaran (difficulty index) dihitung menggunakan persamaan:

$$
\text { Tingkat Kesukaran }(T K)=\frac{\text { rata-rata }}{\text { skor maksimum yang ditetapkan }}
$$

Dimana hasil penghitungannya dalam instrumen penalaran matematis ini ditunjukkan pada tabel 4.

Tabel 4. Hasil Hitung Tingkat Kesukaran Soal

\begin{tabular}{|c|c|c|c|c|}
\hline No Soal & Rata-rata & Skor Maksimum & TK & Kategori \\
\hline 1 & 2,667 & \multirow[t]{8}{*}{4,00} & 0,667 & Sedang \\
\hline 2 & 3,417 & & 0,854 & Mudah \\
\hline 3 & 2,750 & & 0,688 & Sedang \\
\hline 4 & 3,417 & & 0,854 & Mudah \\
\hline 5 & 2,750 & & 0,688 & Sedang \\
\hline 6 & 3,333 & & 0,833 & Mudah \\
\hline 7 & 2,750 & & 0,688 & Sedang \\
\hline 8 & 3,083 & & 0,771 & Mudah \\
\hline
\end{tabular}

Hasil hitung tingkat kesukaran di atas kemudian di kategorikan menurut kriteria yang ditetapkan sebelumnya. Analisis tingkat kesukaran masing-masing soal ditunjukkan pada tabel 5.

Tabel 5. Analisis Tingkat Kesukaran Soal

\begin{tabular}{cc}
\hline Kriteria Tingkat Kesukaran & Nomor Soal \\
\hline Sukar & - \\
\hline Sedang & $1,3,5,7$ \\
\hline Mudah & $2,4,6,8$ \\
\hline
\end{tabular}

\section{Daya Pembeda}

Daya pembeda yaitu mampu atau tidaknya soal dalam membedakan siswa yang punya kemampuan tinggi dengan siswa yang berkemampuan rendah. Rumus untuk menentukan DP soal bentuk uraian ialah sebagai berikut: ${ }^{19}$

$$
\text { Daya Pembeda }(\mathrm{DP})=\frac{B A}{J A}-\frac{B B}{J B}
$$

Daya pembeda soal dihitung menggunaakan bantuan aplikasi Microsoft excel dan didapatkan hasil hitung DP tiap soal disajikan dalam tabel 6.

\section{Tabel 6. Nilai Daya Pembeda Setiap Soal}

\begin{tabular}{ccccccccc}
\hline No.Soal & $\mathbf{1}$ & $\mathbf{2}$ & $\mathbf{3}$ & $\mathbf{4}$ & $\mathbf{5}$ & $\mathbf{6}$ & $\mathbf{7}$ & $\mathbf{8}$ \\
\hline DP & 0,58 & 0,25 & 0,33 & 0,33 & 0,42 & 0,33 & 0,42 & 0,33 \\
\hline
\end{tabular}

\footnotetext{
${ }^{18}$ Ida Farida, Evaluasi Pembelajaran Berdasarkan Kurikulum Nasional, hlm. 156.

${ }^{19}$ Elis Ratnawulan, dkk. , Evaluasi Pembelajaran, 167-168
} 


Kriteria $\quad$ Baik Sedang Cukup Cukup Baik Cukup Baik Cukup

Analisis daya pembeda soal tersebut dapat dikategorikan menurut kriteria tertentu yang ditunjukkan dalam tabel 7.

Tabel 7. Analisis Kriteria Daya Pembeda

\begin{tabular}{cc}
\hline Kriteria & Nomor Soal \\
\hline Buruk & - \\
\hline Sedang & 2 \\
\hline Cukup & $3,4,6,8$ \\
\hline Baik & $1,5,7$ \\
\hline Baik Sekali & - \\
\hline
\end{tabular}

Berdasar pada analisis yang telah dilakukan, dapat menggambarkan bahwa soal cukup baik dalam membedakan siswa yang sudah paham akan materi dengan siswa yang belum paham akan materi yang telah diajarkan.

Berdasarkan kisi-kisi tes dalam penelitian ini, keseluruhan soal yang memuat 8 butir soal sudah sesuai dengan persyaratan tes. Soal ini kemudian diterapkan untuk memperoleh data terkait kemampuan penalaran matematis siswa. Hasil rekapitulasi analisis butir soal ditunjukkan pada tabel 8 .

Tabel 8. Rekapitulasi Hasil Uji Coba Soal

\begin{tabular}{cccccc}
\hline $\begin{array}{c}\text { No. Butir } \\
\text { Soal }\end{array}$ & Validitas & Reliabilitas & $\begin{array}{c}\text { Tingkat } \\
\text { Kesukar-an }\end{array}$ & $\begin{array}{c}\text { Daya } \\
\text { Beda }\end{array}$ & Keterangan \\
\hline 1 & Valid & Tinggi & Sedang & Baik & Dipakai \\
\hline 2 & Valid & Tinggi & Mudah & Sedang & Dipakai \\
\hline 3 & Valid & Tinggi & Sedang & Cukup & Dipakai \\
\hline 4 & Valid & Tinggi & Mudah & Cukup & Dipakai \\
\hline 5 & Valid & Tinggi & Sedang & Baik & Dipakai \\
\hline 6 & Valid & Tinggi & Mudah & Cukup & Dipakai \\
\hline 7 & Valid & Tinggi & Sedang & Baik & Dipakai \\
\hline 8 & Valid & Tinggi & Mudah & Cukup & Dipakai \\
\hline
\end{tabular}

Berdasarkan Tabel 8 setelah dilakukan beberpa uji butir soal, maka dapat diambil kesimpulan bahwa seluruh butir soal sudah memenuhi syarat dan sesuai kriteria yang diharapkan. Sehingga soal tes dapat diterapkan dengan tujuan untuk mengukur kemampuan penalaran matematis siswa dalam penelitian ini.

\section{Uji Hipotesis}

\section{Analisis Deskripsi}

Analisis deskriptif untuk mengetahui hasil analisis yang telah dilakukan, apakah dapat menggeneralisasikan hipotesisnya atau tidak. Hasil penelitian dapat diterima jika $\mathrm{Ha}$ diterima. Tahap yang dilakukan pertama kali ialah mengoreksi jawaban dari pretest dan posttest sesuai kunci jawaban dan pedoman penskoran Kriteria penskoran dari rubrik yang digunakan memiliki skala $0-4$ yang kemudian ditransformasukan dengan cara berikut ini:

$$
\mathrm{S}=\mathrm{R} / \mathrm{N} \times 100
$$

Data hasil pretest dan posttest yang didapat kemudian dihimpun dalam bentuk tabel yang dapat dilihat pada distribusi frekuensi tabel 9 berikut.

Tabel 9. Distribusi Frekuensi Hasil Nilai Pretest dan Posttest

\begin{tabular}{ccccc}
\hline \multirow{2}{*}{ No } & \multirow{2}{*}{ Interval } & \multirow{2}{*}{ Kriteria } & \multicolumn{2}{c}{ Frekuensi } \\
\cline { 4 - 5 } & & & pretest & posttest \\
\hline 1 & $80-100$ & Sangat Baik & 3 & 7 \\
\hline 2 & $60-79$ & Baik & 3 & 4 \\
\hline
\end{tabular}

28 Ulya, Agustyarini - Pengaruh Pendekatan Pendidikan Matematika Realistik terhadap Kemampuan Penalaran 


\begin{tabular}{ccccc}
\hline 3 & $40-59$ & Cukup & 5 & 1 \\
\hline 4 & $20-39$ & Kurang & 1 & - \\
\hline \multicolumn{3}{c}{ Jumlah } & 12 & 12 \\
\hline
\end{tabular}

Data yang didapat dari instrumen penelitian kemudian dibuat tabel deskriptif statistik dengan mencari nilai tertinggi $\left(\mathrm{X}_{\max }\right)$ dan nilai terendah $\left(\mathrm{X}_{\min }\right)$ pada data pretest maupun post test. Selanjutnya dicari rataan $(X)$, nilai tengah $\left(M_{e}\right)$, modus $\left(M_{o}\right)$, serta jangkauan $(R)$ dan simpangan baku (S). Hasil perhitungan tersebut ditunjukkan pada tabel 10.

Tabel 10. Statistik Deskripsi Skor Kemampuan penalaran Matematis

\begin{tabular}{cccccccc}
\hline Test & $\mathbf{X}_{\max }$ & $\mathbf{X}_{\min }$ & $\mathbf{X}$ & $\mathbf{M}_{\mathbf{e}}$ & $\mathbf{M}_{\mathbf{o}}$ & $\mathbf{R}$ & $\mathbf{S}$ \\
\hline Pretest & 88 & 38 & 64 & 63 & 56,25 & 50 & 16,401 \\
\hline posttest & 100 & 53 & 80 & 84 & 87,5 & 47 & 14,441 \\
\hline
\end{tabular}

\section{Uji Normalitas}

Untuk menguji hipotesis ini maka data di analasis menggunakan uji pair sampel T-Test. Dimana syarat uji pair sampel T-Test ialah data harus berdistribusi normal. Sehingga dilakukan uji normalitas dengan metode Liliefors pada data pretest dan posttest untuk menguji normalitas data. Uji normalitas data pretest dan posttest kemampuan penalaran matematis siswa ditunjukkan pada tabel 11.

Tabel 11. Hasil Uji Normalitas

\begin{tabular}{|c|c|c|c|}
\hline Tes & $\mathbf{L}_{\text {hitung }}$ & $\mathbf{L}_{\text {tabel }}$ & Keputusan Uji \\
\hline Pretest & 0,11249 & \multirow{2}{*}{0,242} & Normal \\
\hline Posttest & 0,089 & & Normal \\
\hline
\end{tabular}

\section{Uji Pair Sample T-Test}

Setelah diuji normalitas datanya, kemudian dilakukan uji hipotesis pada data pretest dan posttest kemampuan penalaran. Hipotesis dalam penelitian ini adalah sebagai berikut:

$\mathrm{H}_{0}: \mu_{1} \mu_{2}=0$ (Pendekatan Matematika Realistik Indonesia (PMRI) tidak berpengaruh terhadap kemampuan penalaran matematis siswa).

$\mathrm{H}_{1}: \mu_{1}, \mu_{2} \neq 0$ (Pendekatan Matematika Realistik Indonesia (PMRI) berpengaruh terhadap kemampuan penalaran matematis siswa)

Pair sample T-Test diterapkan untuk mencari pengaruh PMRI terhadap kemampuan penalaran siswa dan untuk membandingkan sebelum dan sesudah perlakuan PMRI pada siswa kelas V SDN Trucuk II. Rumus yang diterapkan pada sampel berpasangan atau paired secara manual yaitu : ${ }^{20}$

$$
t_{\text {hitung }}=\frac{\bar{D}}{\frac{S D}{\sqrt{n}}}
$$

Adapun hasil perhitungannya ditunjukkan pada tabel 4.12.

Tabel 4.12. Rangkuman Uji Paired Sample T-Test

\begin{tabular}{lc}
\hline \multicolumn{1}{c}{ Keterangan } & Hasil Hitung \\
\hline $\bar{D}$ (Rata-rata selisih skor pretest dan posttest) & 15,885 \\
\hline$s^{2}$ (variansi) & 48,754 \\
\hline$S D$ (standar deviasi selisih skor) & 6,982 \\
\hline$n$ (jumlah sampel) & 12 \\
\hline t hitung & 7,881 \\
\hline
\end{tabular}

${ }^{20}$ Syofian, Metode Penelitian Kuantitatif,, 191-192. 
Hasil dari $t_{\text {hitung }}$ kemudian dikonsultasikan dengan harga $t_{\text {tabel }}$ dengan signifikansi 0,05 maka dapat diketahui nilai $t_{\text {tabel }}$ adalah 2,201. Karena $t_{\text {hitung }}=7,881>t_{\text {tabel }}=2,201$ kemudian dapat disimpulkan bahwa $\mathrm{H}_{0}$ ditolak. Maka rata-rata selisih pada saat sebelum dan sesudah diterapkannya pendekatan PMRI berbeda. Sehingga dapat dikatakan terdapat pengaruh PMRI terhadap kemampuan penalaran matematis siswa.

\section{Pembahasan}

Penelitian ini meneliti pendekatan PMRI yang menjadi variabel bebas (variabel X) dan kemampuan penalaran matematis siswa sebagai variabel terikat (variabel Y). Sampel dalam penelitian ini menggunakan satu kelas sebagai subjek penelitian, yaitu sebanyak 12 siswa kelas 5 SDN Trucuk II yang diberikan pembelajaran menggunakan pendekatan PMRI. Pembelajaran dilakukan sebanyak 3 kali pertemuan (setiap pertemuan 2 JP x 35 menit. Pada pertemuan pertama dilakukan pretest sebelum pembelajaran dengan instrumen soal penalaran matematis yang telah diuji serta di analisis validitas dan reliabilitasnya. Dari pembelajaran dan pengambilan data yang dilakukan, didapatkan data berupa skor pretest dan posttest.

Proses pembelajaran dilakukan dengan memperhatikan lima karakteristik PMRI dimana karakteristik tersebut tercantum dalam Rencana Pelaksanaan Pembelajaran (RPP). Proses pembelajaran juga dilaksanakan dengan memperhatikan sintaks modell pembelajaran matematika realistik. Maka dengan memperhatikan hal tersebut, pembelajaran selalu diawali dengan hal-hal konkret yang dapat dibayangkan oleh siswa (penggunaan konteks). Pada awal kegiatan dilakukan dengan pemberian semangat oleh peneliti dan mengingatkan kembali tentang materi prasyarat, yaitu tentang luas bangun datar, dimana materi ini sudah pernah didapatkan sebelumnya dan memiliki keterkaitan dengan materri apa yang akan dipelajari, sehingga memenuhi karakteristik "intertwinning".

Untuk mendukung proses pembelajaran, penelliti mengelompokkan siswa menjadi beberapa kelompok yang dibagi secara berhitung, dimana per kelompok terdiri dari 4 siswa. Hal ini mendorong terjadinya karakteristik "interaksi" dalam PMRI. Langkah selanjutnya adalah pemberian Lembar Kegiatan Siswa (LKS) yang membahas tentang konsep volume bangun ruang dalam kehidupan sehari-hari. Disamping itu peneliti juga menyediakan benda konkret sesuai masalah yang perlu diselesaikan dalam kegiatan tersebut, sehingga siswa dapat mendemonstrasikan secara langsung. Maka dari kegiatan tersebut pembelajaran telah memenuhi karakteristik dalam PMRI, yaitu "kontribusi siswa".

Dengan adanya benda konkret yang dapat didemonstrasikan tersebut, pembelajaran menjadi lebih bermakna sehingga dapat membantu siswa dalam rangka pemodelan (model of maupun (model for) serta melakukan matematisasi vertical. Karakteristik "interaksi" dipenuhi ketika guru memberi peluang untuk siswa agar berdiskusi dan interaksi dengan temannya, disamping itu guru mempersilahkan siswa untuk bertanya jika terdapat kesulitan.

Melalui kegiatan yang telah dilakukan, siswa diminta menjelaskan penyelesaian soal tersebut bersama temannya. Kemudian guru memberi penguatan pada siswa mengenai hasil diskusi setiap kelompok. Sehingga melalui kegiatan ini terjadi interaksi antar teman sejawat maupun antara siswa dengan guru.

Dari pembelajaran yang dilakukan, didapatkan data berupa skor pretest dan posttest, yang kemudian dihitung dan disajikan dengan analisis deskriptif. Hasil dari analisis deskriptif diketahui rerata nilai pretest adalah 64 sedangkan skor posttest adalah sebesar 80 . Kriteria skor pada pretest yaitu terdapat 3 anak dengan kriteria kemampuan sangat baik, 3 anak dengan kriteria baik, 5 anak dengan kriteria cukup, dan seorang anak memiliki kriteria kemampuan kurang. 
Sedangkan pada skor posttest terdapat 7 anak yang meraih skor dengan kriteria sangat baik, 4 anak dengan kriteria baik dan seorang anak dengan kriteria cukup. Berdasarkan dari hasil analisis data yang telah dilakukan, maka dapat diperoleh hasil analisis dan berikut ini pembahasanya:Penelitian ini bertujuan untuk mengetahui apakah penggunaan pendekatan PMRI berpengaruh terhadap kemampuan penalaran matematis siswa kelas $\mathrm{V}$ pada materi bangun ruang. Dari penerapan pembelajaran yang telah dilakukan pada siswa kelas V di SDN Trucuk II dengan menerapkan PMRI, siswa dituntut agar aktif saat pembelajaran dan diarahkan untuk dapat memperagakan suatu model atau membayangkan masalah agar dapat menyelesaikan soal. Hal ini selaras dengan yang disampaikan de Lange yang mengatakan bahwa pembelajaran harus dapat memberikan pengalaman konkret, sehingga siswa bisa terlibat secara langsung pada kegiatan belajar matematika. ${ }^{21}$

Dalam penelitian ini, peneliti berperan sebagai fasilitator belajar dengan menyampaikan permasalahan yang nyata yang dapat diimajinasikan oleh siswa, menyiapkan media dan memotivasi siswa. Pada proses pembelajaran dilakukan dengan berpedoman pada RPP yang didalamnya berisi kegiatan yang mengandung karakteristik PMRI.

Berdasarkan analisis dari data pretest dan posttest dengan uji paired sample t-test (tabel 4.13) didapatkan harga $t_{\text {hitung }}$ sebesar 7,881 yang kemudian dibandingan dengan $t_{\text {tabel }}$ dengan taraf signifikansi sebesar 0,05 yaitu didapatkan hasil 2,201. Sehingga $t_{\text {hitung }}>t_{\text {tabel }}$, maka diperoleh bahwa $\mathrm{H}_{0}$ ditolak. Sehingga dapat diartikan bahwa pendekatan PMRI berpengaruh terhadap kemampuan penalaran matematis siswa kelas $\mathrm{V}$ pada materi bangun ruang.

Hal ini sejalan dengan penelitian Sri Kurniati yang melakukan penelitian sejenis namun dengan metode penelitian berbeda, disampaikan bahwa terdapat pengaruh pendekatan Pendidikan Matematika Realistik Indonesia (PMRI) terhadap kemampuan penalaran matematis siswa kelas VIII SMP. Disandingkan dengan penelitian ini, didapatkan hasil bahwa pendekatan PMRI juga mempengaruhi kemampuan penalaran matematis siswa kelas V Sekolah Dasar.

Dalam tabel 4.11 telah disajikan data pretest dan posttest yang memuat statistik deskripsi skor kemampuan penalaran matematis siswa dapat ditunjukkan bahwa rata-rata skor pretest yaitu 64, sedangkan rata-rata skor posttest setelah pembelajaran PMRI sebesar 80. Maka dari hasil yang telah didapat, dapat diambil konklusi bahwa rata-rata skor siswa meningkat setelah proses pembelaiaran dengan pendekatan PMRI.

Berdasarkan penjabaran di atas, kesimpulannya yaitu pembelajaran yang menggunakan pendekatan Pendidikan Matematika Realistik Indonesia berpengaruh terhadap kemampuan penalaran matematis siswa. Hal ini didukung oleh teori dasar lahirnya pendekatan PMRI, yaitu teori konstruktivisme yang mengatakan bahwa pengetahuan berasal dari hasil konstruksi manusia itu sendiri. Sehingga dengan siswa mengonstruksi pengetahuannya sendiri maka dapat melatih siswa dalam proses bernalar. Selaras dengan hal tersebut, lima karakteristik pendekatan PMRI meliputi penggunaan konteks; penggunaan model; penggunaan konstruksi siswa; adanya interaksi; dan keterkaitan. Dimana kemampuan penalaran matematis siswa dapat dikembangkan melalui implementasi kelima karakteristik pendekatan PMRI tersebut dalam proses pembelajaran.

\section{Kesimpulan}

Berdasarkan pada hasil analisis data yang telah dilakukan dan dari pemaparan pembahasan, didapatkan hasil $t_{\text {hitung }}$ dari uji paired sample t-test sebesar 7,881 dan harga $t_{\text {tabel }}$ dengan taraf signifikansi 0,05 sebesar 2,201. Didapatkan harga $t_{\text {hitung }}>t_{\text {tabel }}$ sehingga $H_{0}$ ditolak. Maka dapat diambil kesimpulan bahwa penerapan pendekatan Pendidikan Matematika Realistik Indonesia

${ }^{21}$ Sutarto Hadi, Pendidikan Matematika Realistik: Teori, Perkembangan, dan Implementasinya, .. , hlm. 29. 
(PMRI) positif terhadap kemampuan penalaran matematis siswa kelas $\mathrm{V}$ pada materi bangun ruang.

Berdasarkan pada penelitian yang telah dilaksanakan, terdapat beberapa catatan peneliti yang dapat digunakan, antara lain: (1) Penelitian tentang kemampuan penalaran matematis siswa sebaiknya dilakukan dengan waktu dan sampel yang cukup sehingga hasil penelitian dapat lebih representative (2) Saran bagi guru, pendekatan PMRI sebaiknya digunakan untuk proses pembelajaran matematika. (3) Diharapkan lebih mempelajari dan menguasai tentang urutan pembelajaran dengan PMRI dan mengenali metode pembelajaran yang sering dilakukan siswa sebelumnya agar peneliti selanjutnya dapat menyesuaikan dan menerapkan PMRI dengan lebih baik. (4) Penulis menyadari bahwa masih sederhananya penelitian ini dimana hasil dari penelitian ini bukanlah proses akhir. Sehingga perlu dillakukan penelitian lebih lanjut yang berkenaan dengan penerapan PMRI dalam peningkatan penalaran matematis siswa secara lebih mendalam. 


\section{Daftar Pustaka}

Badan Standar Nasional Pendidikan. (2016). Salinan PP Nomor 22 Tabun 2016. Retrieved from http://bsnp-indonesia.org

Berdasarkan survey dan wawancara pra observasi, (Bojonegoro: 9 Juni 2020)

Departemen Agama RI. (2006). Al- Qur'an dan Terjemahannya, Jakarta: CV. Pustaka Agung Harapan.

Hadi, Sutarto. (2017). Pendidikan Matematika Realistik: Teori, Pengembangan dan Implementasinya. Jakarta: RajaGrafindo Persada.

Hulukati, Evi. (2014). Matematika Realistik. Yogyakarta: Deepublish CV Budi Utama.

Kusumaningrum, Dwi Sulistya. (2016). Peningkatan Kemampuan dan Kemandirian Belajar Matematika Melalui Pendidikan Matematika Realistik Indonesia (PMRI) untuk Siswa SMP. jurnal, vol.1, no. 1

Niluh \& Endang. (2012). Instrumen Penelitian "Kemampuan Matematika". makalah. Yogyakarta: Universitas Negeri Yogyakarta.

Putrawangsa, Susilahudin. (2017). Desain Pembelajaran Matematika Realistik. Mataram: CV. Reka Karya Amerta.

Ratnawulan, Elis, dkk. , Evaluasi Pembelajaran,

Sa'adah, Widayanti Nurma. (2010). Peningkatan Kemampuan Penalaran Matematis Siswa Kelas VIII SMP Negeri 3 Banguntapan dalam Pembelajaran Matematika melalui PMRI, Yogyakarta: UNY.

Siregar, Syofian. (2017). Metode Penelitian Kuantitatif. Jakarta. Penerbit Kencana.

Sudijono, Anas. (2013). Pengantar Evaluasi Pendidikan. Jakarta: PT Raja Grafindo.

Sukirman dkk. Matematika. Modul. Jakarta: Penerbit Universitas Terbuka.

Susanah. Matematika dan Pendidikan Matematika. Modul. (Jakarta: Universitas Terbuka).

Wibowo, Aji. (2017). Pengarub Pendekatan Pembelajaran Matematika Realistik dan Saintifik terhadap Prestasi Belajar, Kemampuan Penalaran Matematis Sdan Minat Belajar, jurnal riset Pendidikan matematika 4. 